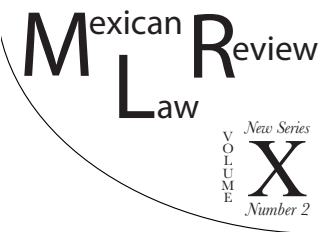

\title{
THE MODERN POSSIBILITIES OF HUMAN RIGHTS. A CRITIQUE OF THE NEGATIVE CRITIQUE OF LAW AND RIGHTS
}

\author{
Sergio Martín Tapia Argüello*
}

\begin{abstract}
"I knew that it is not only over different works, in the long course of centuries, but over different parts of the same work that criticism plays, thrusting back into the shadow what for too long has been thought brilliant, and making emerge what has appeared to be doomed to permanent obscurity". Marcel Proust (1925:1062). The Guermantes way.
\end{abstract}

\begin{abstract}
This note analyzes the relations between human rights discourse and Critical Legal Theory, focusing on what can be called "the negative critique of law and rights". Although the negative critique is important to any kind of critical approach (especially those which deal with something that seems beyond the possibilities of the critique), the note presents the multiple problems of the total rejection of human rights in contemporary societies.
\end{abstract}

Key Words: Critical Legal Studies, Marxism and lare, Critical Legal Thinking, Human Rights, Negative philosophy.

RESUMEN: El presente trabajo analiza las relaciones entre el discurso de los derechos humanos y la Crítica Furídica, y se enfoca principalmente en lo que puede llamarse la "critica negativa" al derecho y los derechos. A pesar de la importancia que tiene la crítica negativa para todo discurso crítico (especialmente para aquellos que estudian algo que parece estar más allá de las posibilidades de la crítica), el artículo presenta los múltiples problemas que existen en un rechazo total a los derechos humanos en las sociedades contemporáneas.

Palabras Clave: Crítica jurídica, Marxismo y derecho, Pensamiento jurídico crítico, Derechos humanos, Filosofia negativa.

* PhD. researcher, Centro de Estudos Sociais, Universidade de Coimbra (Portugal). This essay is co-funded by the European Social Fund through the Human Potential Operating Program and by the Portuguese Foundation for Science and Technology through the doctoral grant PD/BD/114073/2015. 
Esta revista forma parte del acervo de la Biblioteca Jurídica Virtual del Instituto de Investigaciones Jurídicas de la UNAM

\section{Table of Gontents}

I. INTRODUCTION

II. CritiQue And Theory .............................................................. 142

1. The Concept of Critique .................................................... 142

2. Traditional Theories and Critical Theories......................... 143

III. Gritical Legal Thinking...................................................... 147

1. Traditional and Critical Theories of Law ............................ 147

2. A Possible Division of Theories of Law .............................. 148

IV. The negative GritiQue Of HUMAn Rights................................. 150

1. The Negative Critique Based on Ideals ............................. 151

2. The Negative Critique Based on Results ............................ 152

V. Conclusion …........................................................................... 153

\section{INTRODUCTION}

As a member of the group "Critica furídica Latinoamericana" (Latin-American Critical Legal Thinking or "CriJur" ${ }^{1}$ and as someone who presents himself as a critical legal thinker, I am used to hearing some questions about the Critical Legal Thinking (CLT) as well as objections or responses to certain statements allegedly used by the CLT "in general". In some cases, behind these reactions it is possible to find misunderstandings about the CLT approach to law and rights, ${ }^{2}$ but mostly, there are wrong generalizations of certain forms of critique or the presumption that the thought of a particular critical theorist is a perfect and inclusive representation of the general (and homogenous) CLT. ${ }^{3}$

1 To see the history of the group, see Antonio Garlos Wolkmer, Introducción aL Pensamiento Jurídico Crítico (Instituto Latinoamericano de Servicios Legales Alternativos 2003). Nevertheless, it must be recalled that Crijur is not an adaptation of European or North American critical approaches thre are histories of actual hutheWolkmer, 2003. It is not an adaptation of European the law, there are histories of actual huto the law and the rights thre are histories of actual hutheWolkmer, 2003. It is not an adaptation of european the law, there are histories of actual hu, as the global north visions try to present, but one of the most influential perspectives in the construction of the Critical Legal Thinking (CLT), based on the practical struggles for the common people in Latin America made by lawyers, activists, academics and other people. To understand the power of this differentiation, see Oscar Correas (2013), "Conferencia Inaugural" in VIII Conferencia Latinoamericana de Crítica furídica fornada Argentina, Universidad Nacional de La Plata, La Plata, available at http://www.youtube.com/ watch? ${ }^{2}=$ f7WdKU8nkbs (February 15, 2015).

2 Cf. Мотодкі Funakoshi, Taking Duncan Kennedy Seriously: Ironical Liberal Legalism, 15 WIDENER LAW REVIEW 1, 231-236 (2009): to see good abstract and possible answers.

${ }^{3}$ Cf. Ronald Dworkin, El imperio de la justicia, De la teoría general del derecho,

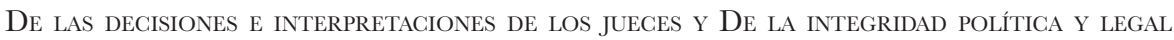


The first impulse when someone raises these arguments is to try to explain "what is the CLT". Nevertheless, this can be hard: to make a "general explanation" of the CLT or to present a particular approach under the assumption that it can incorporate all the CLT, is to make exactly the same mistake that is being criticized. On the contrary, if the critical perspectives have something in common it is the capacity to see the difficulties that can be generated from a univocal definition, ${ }^{4}$ specially to understand something so broad and dynamic as the CLT.

However, this does not mean that definitions are useless or impossible. The problem with definitions is the possibility of a "closed category" that could be understood as a complete (and in this sense, eternal) representation of the reality. ${ }^{5}$ In this case, the definition is presented as the reality itself, and creates a strong normative power over others in their relation with both the definition and the reality. It creates a "Procrustean bed," in which every interpretation/creation of the world must be adapted to be understood as correct.

For the critical theory, these kinds of limits are just a way to create an ideological naturalization of the status quo, presenting the "existence" as the only possible reality. So, it is necessary to understand and accept the existence of open categories, ${ }^{7}$ definitions that are not perpetual and immutable but adaptable and changeable. ${ }^{8}$

It must be considered that there is a possible paradox in this statement. If the possibility of a closed category is accepted, so should be the existence of some kind of essence or nature that could be used to create those categories. We need to remember that even when they are presented as such, the necessary dynamism of a definition, the multivocal ${ }^{9}$ characterization of every concept, the complexity of the social and limited phenomena that we call "reality", make impossible a closed definition of anything at all. Just like the proverbial shield of Achilles, ${ }^{10}$ even if definitions are the most detailed and

COMO CLAVE DE LA TEORÍA Y PRÁCTICA, 191-197 (Gedisa 1992). All translations from works in another language are my own.

4 Mauricio Beuchot, Tratado de Hermenéutica Analógica (Universidad Nacional Autónoma de México 2009).

${ }^{5}$ Max Horkheimer \& Theodor W. Adorno, Dialéctica de la Ilustración, 29-32 (Akal, 2007).

${ }^{6}$ Ovidio, Las Metamorfosis (Editores Mexicanos Unidos, 2008) talks about Procrustes and the way he used to treat the people who accepted to sleep in his place. When someone was bigger than the bed, he just cut their feet or heads off. If they were shorter, he used it like a torture rack until the person died.

7 That is, categories that are understand as mutable and unfinished artificial constructions of an epistemological work and not as "objective" representations of the "reality".

8 Karl Marx, Introducción General a la Crítica de la Economía Política/1857, 5059 (Siglo XXI, 1974) (1857).

9 Beuchot, supra note 4.

10 The shield of Achilles is described in the book eighteen of the Iliad in the most detailed way possible. Nevertheless, there are multiple interpretations of its meaning, and even physical 
explicit descriptions, they will not say the same thing to different people or not even to the same people in different contexts.

The aim of the present paper is to explain a concrete practice of human rights: the construction of theorizations that produce and generate the rationalities and epistemic presumptions which are leading to the other practices involved in this social process. Although problematic, ${ }^{11}$ this point of view remembers us that "all the social life is practice" 12 and every interpretation of the world (even in a theoretical way) is a way to transform it. ${ }^{13}$

In this sense, this note begins with the settings, the characteristics, and the differences between the traditional and critical theories in a reinterpretation of the Frankfurt School perspective. In a second part, it tries to present how this theoretical framework can help us understand the law, both in a negative and a positive way. Finally, I put forward the idea of the rights and how they are observed by the negative criticism.

\section{Critique and Theory}

\section{The Concept of Critique}

Besides the multiple interpretations that the word "critique" can have, there are different possible meanings of it. It is possible to compare the "Critique of pure reason", ${ }^{14}$ in which the word critique can be used as a synonym of a "detailed analysis," which presents itself as a neutral description, or the "Contribution to the critique of the political economy," 15 in which there are both an analysis and a political perspective about the subject, with the phrase: "the patient is in critical condition", to see some of the differences between the meanings of the word. ${ }^{16}$

representations, with an important number of differences between them. Cf. Homero, LA ILIADA, 478-608 (Universidad Nacional Autónoma de México, 2014).

11 As the impossibility of the theory to be understood as a practice in Adolfo Sánchez Vázquez, Filosofía de la Praxis (1980).

12 Karl Marx, Tesis sobre Feuerbach in La Cuestión Judía y Otros Escritos (Planeta, Agostini, 1994).

${ }^{13}$ I use in this case the most known phrase of the Thesis about Feuerbach to make "another turn of the screw". The interpretation is always a transformation; nevertheless. Only the critical perspectives accept the union of these characteristics and in this sense, only for them it is possible to use the transformative process in an emancipatory way. ERnst Bloch, PrinciPIO EsPeranza 1, 11 (Trotta, 2008).

14 Immanuel Kant, Crítica de la Razón Pura (Colihué, 2007)

15 Karl Marx, Contribución a la Crítica de la Economía Política i (Progreso, 1989).

16 Oscar Correas, Grítica de la Ideología Jurídica, 135,147 (Universidad Nacional Autónoma de México, 1988) finds at least seven possible meanings of "critique," including these three. 
Leaving aside the idea about the "critical condition", we can see a similarity between the others: the critique is a detailed analysis about something. The difference between them is political: In the first case, the analysis starts with the idea that it is possible to separate the "object" under study and the "subject" who is studying. Moreover, the separation is possible even between the process of knowledge itself and the constitutions of the subject and the object. Despite the ideological power of this idea, ${ }^{17}$ there are some examples of attempts to prove it wrong: "The critics, on the other hand, share the idea that the science intervenes on the production and construction of its own object, at the same time they explain it by categories and concepts. In this way, it can participate on the realization of its attributed social functions and in the fictions that structure it." ${ }^{\prime 18}$

In this sense, we need to remember that the word "critique" shares the same etymological root with the word "crisis". ${ }^{19}$ This is not just a coincidence; the long traditions of critical studies recognize themselves as they put in crisis (or maybe we can say that they unveil the permanent crisis) the domination relations experienced in our societies. In contemporary times, it must be said that they put in crisis the apparently completeness and perfection of capitalism. Even if some theory presents itself as critical, we need to search for this post-capitalist, or even more important "post-domination" horizon, to classify them as traditional or critical approaches.

As we have seen so far, there are two ways, perhaps not mutually exclusive, of theorizing. This division, which assumes the existence of a "traditional" way to make theory and a "critical" one, arises from Max Horkheimer's work. ${ }^{20}$

\section{Traditional Theories and Critical Theories}

According to the vision of this author, there are multiple ways of doing and classifying theories. The central classification, nevertheless, is based on the idea of tradition or critique. Perhaps the most important difference between them is that while traditional theories assume the naturalness, immutability, need, or essentiality of certain elements as historical, critical theories struggle against this vision. A good example of this is the Marxist analysis: "the purpose of Marx's analysis was to undermine the apparent solidity of bourgeois categories, to show that they were not given by nature but expressed historically transient forms of social relations". ${ }^{21}$

17 Cf. Norberto Bobbio, La filosofia política y la lección de los clásicos in TeOría General de la Política, 86-89 (Trotta, 2003).

18 Alicia E. C. Ruiz, Derecho, democracia y teorías críticas de fin de siglo in IDAS y Vueltas Por Una Teoría Crítica del Derecho, 5 (Editores del puerto, 2001).

19 John Holloway, Gambiar el Mundo Sin Tomar el Poder, El Significado de la RevoLución Hoy (Sísifo ediciones, 2010).

20 Max Horkheimer, Teoría tradicional y teoría critica in TeOría Crítica (Amorrortu, 2008).

21 John Holloway El Estado y la Lucha Cotidiana, 24, 13 (Cuadernos políticos 1980). 
For traditional theories, the "facts" exist for themselves and they have a completely independent nature of social relationships through which they are "manifested". ${ }^{22}$ To this kind of approach, if there are variations between two different observers while approaching an "object" must be a mistake from one or even both of them. As the "object" (and with this concept it is possible to talk about a stone, a river, the manual labor in the south of Coimbra, etc.) exists by itself, it has some implicit and natural characteristics that cannot be changed at all by the interpreters, but only misunderstood. This kind of essentialism implies the belief that the world is something immutable, which exists outside of us and therefore we have no choice but to accept it. ${ }^{23}$ This is certainly a theory of immobility, which leads to thinking that nothing can be transformed, so the only way to achieve social harmony, is precisely to put away the idea of transformation. ${ }^{24}$

On the other hand, critical theories understand that "the circumstances are changed by humans". ${ }^{25}$ In capitalistic societies, "the world", "the reality," is just presented as a group of facts, as "something" that has an independent and previous existence. In this sense, we just need to "observe" and to analyze it. Nevertheless:

By critical theory I understand all kind of theories that do not accept the reduction of the "reality" to what exists. The reality, however you want to conceive it, is considered by the critical theory as a field of possibilities, and the work of the theory is precisely to define and evaluate the nature and the space of the alternatives to what is given empirically. The critical analysis of the existence is based on the presumption that what already exists cannot fulfill the entire existence, so, it is based on the idea that there are alternatives that allow to go beyond what is criticized in what exists. ${ }^{26}$

Villages, houses, clothes, law and rights, all the social process that Durkheim tries to present as "things", are products of the general social praxis. This means that they are socially preformed in two ways; both the process

${ }^{22}$ Maybe the most important example of this can be found in the work of ÉmILE DuRKheim, Las Reglas del Método Sociológico, 7 (Editorial Folio, 2007) for whom "the social facts must be treated like things".

23 In some cases, this is even presented as the best possible world. Cf. G. W. Leibniz (2005) Theodicy/Essays on the Goodness of God, the Freedom of Man and the Origin of Evil, The Project Gutenberg Евоокs (February 28, 2016), http://www.gutenberg.org/ebooks/17147.

${ }^{24}$ This is not a random idea. Durkheim itself used it when he talked about the social division of labor. Cf. Émile Durkheim, La División del Trabajo Social (Colofón, 2002).

25 MARX, supra note 12.

26 Boaventura de Sousa Santos, Crítica de la Razón Indolente. Contra el Desperdicio de la Experiencia. Para un Nuevo Sentido Común: La Ciencia, el Derecho y la Política en la Transición Paradigmática, 23 (Desclée de Brouwer, 2003). 
and the subject that interprets them are part of the history itself, ${ }^{27}$ and they perform a historical process when interacting with each other. ${ }^{28}$

There is evidence that ancient Greeks had theoretical and technological knowledge for line production and mechanization. Even so the potential transformation of the production of goods and social relations ${ }^{29}$ had to wait for the emergence of a specific set of knowledge, ways of understanding, apprehending and living in the world in order to be considered possible. ${ }^{30}$ The Greek's small steam - propelled toys or the ships with steam engines presented to the German - Spanish king Carlos V, were just curiosities without any kind of practical application for them. They could change the history of the world, but the social and economic characteristics of both societies did not adjust to the social transformation required for that.

The importance of these examples is not to present the idea of some kind of "nature" or "essence" of Ancient Greece or Medieval Spain, but to confirm the relevance of the historical, social and economic process in the "creation" of the "products". To present itself as a social necessity, the line production needs the existence of the "commodity" a specific form of social relationship that did not exist before capitalism. ${ }^{31}$ It is based on the separation of the worker and the product of his work and the appropriation of the result of this separation by another. Without the necessity of mass production in modern societies and without the specific form of social relation called commodity, with a political system based on the slavery and without the idea of the surplus value, the steam machine was not able to transform the social way of production, although the physical apparatus was already invented.

This attempt to hide the historical and social construction of the "objects" happens in theoretical and scientific work too. In a society where the social division of labor implies more than just a neutral separation of specialized knowledge, which is presented as a non-ideological process of differentiation based on specific requirements generated by external and autonomous entities, all the elements are in a constant process of fetishization, in which theory is separated from science. ${ }^{32}$ In this way, science can be presented as "clean and neutral," different and separate from the process that allows the existence of historically defined theories. However, this kind of artificial division forgets that:

\footnotetext{
27 Horkheimer, supra note 20 at 233.

28 Pierre Bourdieu, El Oficio de Sociólogo (Siglo XXI, 2008).

29 Karl Marx, Trabajo asalariado y capital in La Guestión Judía y Otros Escritos, 315 (Planeta, Agostini, 1994).

30 Juan Ramón Gapella, Fruta Prohibida. Una Aproximación Histórico Teorética al Derecho y al Estado (Trotta, 2008).

31 Karl Marx, El Capital, Crítica de la Egonomía Política, 37 (Fondo de Cultura Económica, 2008).

32 Max Horkheimer \& Theodor W. Adorno, Filosofia y división del trabajo in Dialéctica DE LA Ilustración, 262-263 (Akal, 2007).
} 
Neither the structure of the production, divided into industrial and agrarian, nor the separation between the so called directive and executive functions, between services and jobs, or manual and intellectual occupations, are eternal or natural situations; however, they come from the specific mode of production of a specific society. The illusion of independence offered by work processes (which run itself, correspond to) the apparent freedom of economic subjects within bourgeois society. They believe they act based on personal choices, when, even in its most complicated speculations, they are exponents of the ungraspable social mechanism. ${ }^{33}$

Within these arguments, there are strong refutations to the ideas of "progress" and "development". While in the political and economic-social sphere these concepts have been widely criticized and its indiscriminate use has decreased, sciences, especially those involved in technical issues, maintain some kind of evolutionary discourse. The history of science and technology is still seen in many cases as a progressive linear story, in which scientific and technological knowledge is always enhanced and never diminished. The traditional discourse about them presents the idea that we know more now than before, in more "efficient" and "accurate" ways, even if these concepts are not properly explained, but just understood as intuitive or obvious. It is a knowledge based on a proleptic reason, ${ }^{34}$ which does not need to explain or justify itself.

A critical stance, on the other hand, remembers that these processes are not isolated, unique, or unidirectional. A "paradigm shift" in science is not brought about by the logical qualities of the new system; it does not occur because the new approach is more accurate or actually "better" in an abstract and essential way than the previous visions. ${ }^{36} \mathrm{~A}$ change of this type is part of a complete social reconfiguration. The transformation of a system of production and reproduction (both material and social) allows the appearance, the visibility of specific wisdoms and knowledge that maybe already existed in the previous configuration. The difference between them causes that in the new one, some perspectives can be presented as "superior" than others. This does not mean that they are superior in every aspect, but only that that it fits better in the social transformation itself. ${ }^{37}$

When a social reconfiguration arises, the legitimate knowledge creates the idea of its own superiority because it produces, at the same time, the criteria and parameters to be applied in assessing and qualifying all kinds of informa-

\footnotetext{
33 HorkHeIMER, supra note 20 at 231.

34 Boaventura de Sousa Santos, La sociología de las ausencias y la sociología de las emergencias: para una ecología de saberes in Renovar la TeOría Grítica y ReInventar la Emancipación Social (ENCUENTROS EN BUENOS AIRES), 21 (CLACSO, 2006).

35 Thomas S. Kuhn, La Estructura de las Revoluciones Científicas (Fondo de Cultura Económica, 2002)

36 Horkheimer \& Adorno, supra note 32 at 229.

37 Cf. Michel Foucault, La Arqueología del Saber (Siglo XXI, 2007).
} 
Esta revista forma parte del acervo de la Biblioteca Jurídica Virtual del Instituto de Investigaciones Jurídicas de la UNAM

tion. The creation of this monoculture of knowledge and rigor ${ }^{38}$ disavows every representation of the reality outside its own parameters. When this happens, it is easy to observe an improvement of the previous conditions, and at the same time, to ignore the negative aspects of the new configuration. Against this idea, the critical perspectives need an ecology of knowledge ${ }^{39}$ to embrace the multiple points of view of the society and at the same time, to avoid the problems of univocism.

In this scenario, it is clear that critical theories are only possible with hope; but as Bloch said: "hope, situated above the fear, is not passive nor closed in selfemptying"; ${ }^{40}$ hope is action, just like all kind of critique: "there is not such thing as knowledge without praxis, so the "critical" knowledge will be the one that is related with certain kind of action that brings the transformation of the reality," important, action for a better world. ${ }^{42}$

\section{Critical Legal Thinking}

\section{Traditional and Critical Theories of Law}

Based on the above, it is possible to talk about two different, but not mutually exclusive groups of theories: traditional theories and critical theories of law. We can understand as a traditional theory every theoretical (and practical) ${ }^{43}$ approach that begins with the acceptance of some presumptions about the law, the state or the rights based on the same discourse it tries to explain, and that presents them as natural, external or immutable. For traditional theories, there are certain dogmas that need to be accepted if you want to participate in a legal system, and even if you want to make critiques of that system or to transform it.

According to these approaches, to make a critique about the legality of a concrete action, e.g. the arbitrary detention of an "illegal alien", requires the acceptance of the rules that create the legality itself. This means to accept the required division between the society in which the only role of some people is to accept and obey the rules, while others are legitimate to create, interpret and apply them in exclusive. In the same way it is necessary to accept the legitimacy of the categories that are used in the particular case, and as a consequence, the possibility to use them in other cases. If someone

\footnotetext{
38 SANTOS, supra note 34 at 23.

39 Boaventura de Sousa Santos, Más allá del pensamiento abismal: de las líneas globales a una ecología de saberes in Una Epistemología del Sur, 183-184 (Siglo XXI, 2009).

40 Bloch, supra note 13 at 25.

41 Luis Alberto Peluso, O Projeto da Modernidade no Brasil,44 (PUCGaMP, 1994)

42 Correas, supra note 16: 135.

43 About the problem of the theory-practice division, cf. Immanuel Kant, En torno al tópico: Tal vez eso sea correcto en teoría, pero no sirve para la práctica in Teoría y PrÁctica (Tecnos, 2002).
} 
tries to complain about these topics, he or she will be dismissed as "political" (meaning not "neutral" or "objective"), and the critique will be diluted as a "political critique", one that goes beyond the possibilities of the law and does not affect the application of the rules. Along this process, the category "illegal alien" and the social division of power needed for such a category to mean something are presented as external and previous to the law, therefore avoiding the social reproduction that happens inside it.

A good example can be illustrated in the "point of view" of law. ${ }^{44}$ The internal point of view is developed by the people who feel constrained by the rules of a legal system, and the external point of view is only possible if you look at the legal system as a non-mandatory set of rules that do not apply to you. The first case is presented by the citizens of a state or by the people of a community about their own law. The second can be found in an anthropologist that observes a different community without participating in it. Hart thinks that only the people who enjoy an internal point of view are able to see the legal system "as it is". For the anthropologists, the rules of a community will be impossible to understand as a legal system, and they will study them like something else. If this is true, the only way to make a critique about the legal system itself is to be "inside" it, and that means to accept the rules of the system as the limit of the critique. In this way, Hart makes it impossible to be inside a legal system without recognizing it as in force. The critiques made by anthropologists will not be "legal" critiques, but some other kind.

For the critical theories, those divisions between internal and external are artificial; methodological preferences that can and in some contexts must be fought against. If you accept the internal point of view as Hart presented it, ${ }^{45}$ every kind of struggle (about interpretation, power or application) will be a struggle inside the discourse of the "actual law" and not for the construction of a different legal reality. ${ }^{46}$ In this sense, these theories believe that it is possible to make an internal point of view that does not accept all the rules of a system. At the same time, the point of view that is called "external" by this division is just as important as the internal to understand the law. Unsurprisingly, it is common to find critical perspectives that reject the strong disciplinary division proposed by traditional theories. ${ }^{47}$

\section{A Possible Division of Theories of Law}

At this point it is worth mentioning that not all traditional theories of law should be understood as the same. Multiple categories can be identified, be-

44 Herbert Lionel Adolphus Hart, The Concept of Law, 102-103 (Oxford University Press, 1997).

45 It is important to notice that the methodological approach of an internal and external point of view can be reformulated in a critical way. Cf. Correas, supra note 16: 140 \& ff.

46 Cf. Michel Foucault, L'ordre du Discours (1970).

47 E. g. in Hans Kelsen, Teoría Pura del Derecho (Porrúa, 2008). 
cause the order of the concepts is not "natural". ${ }^{48}$ To make this point, it is possible to establish one concrete division inside them. The first kind of traditional theories are those that make an apology for the actual existence of the law. For them, the present configuration of the legal system is the best possible. The law and rights work as required, in every space. When these theories talk about the improvement of the law or the rights, they are actually talking about strengthening the legal institutions, rules and legal process within the legal system. To the extent that one can identify some problem with the legal system, it is due to external factors, such as the "culture" or the "education" of the community, but not because of the nature of the legal system in itself.

Next to the apologetic visions of the law, ${ }^{49}$ we can find the renewing approaches. For them, the ideals of rule of law, legality or rights are correct, but the concrete applications of them in the factual world encounter some troubles. The leading idea of this approach is not the transformation of the presumptions of the law and rights, but some adaptation of the practices in which those are materialized. In doing so, it does not problematize the ideas, but just tries to improve the practices inside the law. In some cases, some improvements in the material life of the people can be accomplished, but the major impulse of this kind of theory is not to make such endeavor. Just like the apologists, subscribers to this approach believe the objective of every theory of law is to describe and understand, and if they make it right, then the society can benefit from that. But if this does not happen, the responsibility will not be on the legal dimension. ${ }^{50}$

In some moments, theories and practices start from a renewing approach to the law and eventually they realize that there are internal contradictions in the ideals they are following. In those cases, they start thinking about the possibilities of transforming those ideals, but always to improve what they believe are the most important needs of the system. They recognize the benefits of the actual existence of the legal institutions, concepts, practices and ideals; they use them both theoretically and in other daily practice; they do not want to abandon the general idea of the law or the existence of rights, but they recognize that there are problems on them, some of which cannot be resolved. When we find this kind of approaches, we can thus talk about a positive critical theory. ${ }^{51}$

48 Michel Foucault, Las Palabras y las Cosas, 7-8 (Siglo XXI, 2009).

49 Florencia Correas, Alcances Sociológicos del Derecho de Trabajo en México (Coyoacán, 2004).

50 For instance, we can see the French "sociological positivism" of law. They were followers of Émile Durkheim and believed that the contemporary institutions of the law do not represent the ideal of the rule of law in the modern society. Instead of talking about "legal personality", "obligations" or "rights", the rule of law needs to start with the idea of social function. E.g. León Duguit, Las Transformaciones Generales del Derecho Privado desde el Código de Napoleón (Coyoacán, 2008).

51 Oscar Correas, Acerca de la crítica jurídica 5, EL OTRO DERECHO 1 (1990). 
In some moments, the theoretical approach to certain parts or to what is understood as the totality of this system is problematized in a different way. When E. B. Pashukanis talks about the incompatibility of the idea of law with the communist society, and the historical necessity to disappear this kind of social relationship, ${ }^{52}$ he is making a negative critical theory. The major difference between the positive and the negative critique is not the "good" or "bad" opinion about the effects or existence of the law and rights, but how they understand the ideas of transformation and reality.

According to a negative perspective, "reality" is just one of the possibilities of existence in a certain moment, an existence in which all the other possible realities that could also exist are denied. Each of these other "denied realities" proves that the existence can be different and in this sense, there is a continuous struggle between the reality that exists and the other possibilities. The mutual opposition between them proves that the struggle is a central part of the existence, and that the reality "as it is" can and even must be changed:

The starting point of theoretical reflection is opposition, negativity, struggle. It is from rage that thought is born, not from the pose of reason, not from the reasoned-sitting-back-and-reflecting-on-the-mysteries-of-existence that is the conventional image of "the thinker".

We start from negation, from dissonance. The dissonance can take many shapes. An inarticulate mumble of discontent, tears of frustration, a scream of rage, a confident roar. An unease, a confusion, a longing, a critical vibration...

That is our starting point: rejection of a world that we feel to be wrong, negation of a world we feel to be negative. This is what we must cling to. ${ }^{53}$

Within the negative critique of the law and the rights, for any kind of use of legality, the legal system and even the rights would be useless or even counterproductive to improve the conditions in society, because they would reinforce the existing problems, ${ }^{54}$ as a process of legitimacy of the actual conditions, or as a simple waste of time. ${ }^{55}$

\section{The Negative Critique of Human Rights}

Since World War II, human rights have attracted an increasing and incontestable relevance worldwide. ${ }^{56}$ The effects (both helpful and perverse) of the positivization process started with the Weimer and the Mexican constitutions,

\footnotetext{
52 E. B. Pashukanis, Teoría General del Derecho y el Marxismo (Grijalbo, 1976).

53 Holloway, supra note 19 at 5-6.

54 Max Horkheimer, Estado Autoritario, 36 (Ítaca, 2006).

55 Georg Lukács, Legalidad e ilegalidad in Historia y Conciencia de Clase, Estudios de Dialéctica Marxista (Razón y Revolución, 2009).

56 Norberto Bobbio, El Tiempo de los Derechos (Sistema, 1991).
} 
both in local circumstances and with the Universal Declaration on international law. They started a new era in liberation struggles and their importance increased with the fall of other discourses and imaginaries of emancipation, like "real socialism". ${ }^{57}$

The possibilities that the human rights discourse brings to the legal arena can be considered responsible for the unusual optimism of the theory and the practice of the law. The Neoconstitutionalism put the "fundamental rights" (claims converted to constitutional rights with universal pretention) as the foundation of a new era of the "rule of law" ${ }^{58}$ The modern iusnaturalism states that the rights are the last stronghold from which they can fight against the formalism of positive law. ${ }^{59}$ Despite the possibility of ideological uses of human rights, they are accepted and used in legal practice and theorization for most of the critical legal thinkers. ${ }^{60}$

However, this optimism is not shared by everyone. There are some voices trying to remind us that in the past we have heard the song of different mermaids, with dreadful results. After all, the capitalism has proved to be an excellent mask maker, ${ }^{61}$ and human rights can be easily transformed into nothing more than a domination process. In this sense, we can find two different forms of negative critique of human rights. For the first one, the major problem can be found in their ideals; for the second, the most problematic issue about them is their results.

\section{The Negative Critique Based on Ideals}

For some authors, the so-called ideals of human rights are just ideological attempts to present liberalism as the only valid source of legitimation on moral issues. In this sense, the critique of "individualism" as a reference to the construction of a moral idea ${ }^{62}$ or the social division of the community

57 Boaventura de Sousa Santos, Sociología Jurídica Crítica. para un Nuevo Sentido Común en el Derecho, 506, 508 (Trotta, 2008).

58 Cf. Luigi Ferrajoli, Los Fundamentos de los Derechos Fundamentales (Trotta, 2001).

59 E. g. Robert Alexy, Teoría de los Derechos Fundamentales (Centro de Estudios Constitucionales, 1993).

${ }^{60}$ Oscar Correas \& Ana María del Gesso, Naturaleza linguística y origen de los derechos humanos in Acerca de los Derechos Humanos, Apuntes para un Ensayo, 11 -20 (Coyoacán, 2003).

61 Marshall Berman, Todo lo Sólido se Desvanece en el Aire, 165 (Siglo XXI, 1998): (o) ur era has found new forms of putting masks and mystify the conficts. One of the most important differences between the XIX and the XX century is that our own century has created a grid of new halos to replace those took away by Marx and Baudelaire. He use of partial and fragmentary discourse of claiming as the human rightscial hardship legal system.

62 Antoni Domenech, De la Ética a la Política. De la Razón Erótica a la Razón INERTE (Crítica, 1998). 
to the formation of new forms of social power ${ }^{63}$ can be understood as negative critiques of human rights based on a critique of the ideals behind them.

We can find another way to elaborate this kind of critique based on the idea of hypocrisy of the ideals within human rights. We can see a good example in Zizek's work "Against human rights". ${ }^{64}$ At the beginning, the author sets out what he believes are the three main ideas behind rights in order to prove that they are in fact used to veil the true intentions of the ideological project of capitalism and euro-centrism. Nevertheless, the main source of this kind of negative critique is without any doubt developed on the Marxian and classical Marxist work:

What a terrible mistake it is to have to recognize and sanction in the Rights of Man modern bourgeois society, the society of industry, of universal competition, of private interest freely following its aims, of anarchy of the selfalienated natural and spiritual individuality, and yet, subsequently, to annul the manifestations of the life of that society in separate individuals and at the same time to wish to model the political head of that society after the fashion of the ancients! ${ }^{65}$

As we can see, for Engels and Marx the ideals of human rights cannot be fulfilled within the capitalist society; however, this society present itself as the only one in which they can be achieved. This contradiction is maybe one of the most important in the emancipatory process based on the human rights, just as Marx and Engels understood when they put what can be read as human rights claims in the Manifesto. ${ }^{66}$

\section{The Negative Critique Based on Results}

The second group of critiques of human rights in a negative sense is based on the problems that emerge from the application of those rights in daily life. For the negative critiques, the use of something that is based on an unequal power structure can perpetuate the domination of that specific relationship, ${ }^{67}$ regardless of the intention or the ideals behind them.

In this sense, the recognition of a right in the legal system can be understood as something useless in the social struggle for emancipation. Even if the "acceptance" of a right or a set of rights can be seen as a success for the

63 Sergio TAPIA, Poder como dominación. Una reducción útil para las visiones tradicionales del derecho, 1, DERECHO Y CRÍTICA SOCIAL 2 (2015).

64 Slavoj Zizek, Against human rights, 34 NEW LEFT REVIEW (2005).

65 Karl Marx \& Friederich Engels, The Holy Family or Gritique of Critical CriTIQUE, 164-165 (Foreign Language Publishing House, 1956).

66 Karl Marx \& Friederich Engels, Manifiesto del partido comunista in La Cuestión Judía y Otros Escritos, 270 (Planeta-Agostini).

67 Horkheimer, supra note 54. 
realignment of forces in the symbolic power, ${ }^{68}$ the negative critique is concerned with the impact of that kind of action. In the first place, the state's recognition of a right means the need for an action about a specific problem of the system. ${ }^{69}$ At the same time, the social movements or groups who are fighting for those concrete claims can be demobilized by and through the simple and formal recognition, even without a functional mechanism of enforcement. ${ }^{70}$ In most cases, this can lead to a step back in the near future. ${ }^{71}$

For others, the use of legal institutions implies the justification of the legal system as a whole and the abandonment of other ways to achieve the objectives of the specific claims. This is the case of the Critical Legal Studies movement, for which the use of the human rights discourse implies the disappearance of radicalism, ${ }^{72}$ and in a certain way, to quit the systemic transformation struggles. In other cases, the use of partial and fragmentary claiming discourse as human rights discourse prevents the configuration of a real and complete political identity, and that means the possibility of articulation with others. The people would use this discourse because of the instantaneous advantage of their own claims, but at the same time it would shut down the possibilities of real emancipation. ${ }^{73}$

\section{Conclusion}

It is necessary to look at these negative critiques, and take them seriously. They make important observations on the dangers and unintended consequences of using the institutional dimension of human rights. Nevertheless, it is also necessary to remember that their vision is just as incomplete as the others. As Critical Race Studies scholars have shown, for instance, it is easy to disown the formal protection of human rights when you have economic, cultural, and symbolic power to defend yourself without them. ${ }^{74}$ In some circumstances, law and rights can be used against others. But it is also possible that the total rejection of the same law or rights could be worse than their strategic use in other contexts.

68 Cf. Charles Taylor, El Multiculturalismo y la "Política del Reconocimiento" (Fondo de Cultura Económica, 1993).

${ }^{69}$ Just like the phrase allegedly used by Trostky in an interview, the old idea of that "all the revolutions are impossible, until they become inevitable", can be reformulated to "to have one right is impossible, until the social pressure make it inevitable".

70 Karl Marx, La cuestión judía in La Cuestión Judía y Otros Escritos (Planeta-Agostini).

71 Marius Pieterse, Eating socioeconomic rights: the usefulness of rights talk in alleviating social hardship, 29, HUMAN RIGHTS QUARTERLY 3, 814-815 (2007).

72 Duncan Kennedy, La crítica de los derechos en los Critical Legal Studies (2006), REVISTA JURÍDICA DE LA UNIVERSIDAD DE PALERMO 47, 49-50.

73 Slavoj Zizek, En Defensa de la Intolerancia (Público, 2010).

74 Kimberle W. CRENSHAw, Raza, reforma y retroceso: transformación y legitimación en el derecho contra la discriminación in CRÍTICA FURÍDICA (Ediciones UniAndes, 2006). 
Esta revista forma parte del acervo de la Biblioteca Jurídica Virtual del Instituto de Investigaciones Jurídicas de la UNAM http://www.juridicas.unam.mx/

There is a great danger within the apologetic view of the intrinsic goodness of the rights and the veil that it creates. But at the same time, it is necessary to remember that behind the abstract problems presented on the law, there are histories of actual human beings that can improve their daily life through and with recourse to the law and rights. ${ }^{75}$ The fate of a single human must be enough to constrain the critical perspectives to make a generalization ${ }^{76}$ about the possibilities of human rights.

The critique must attack the familiar perspective of what exists and at the same time it must try to make a new common sense that can overpower the internal inequalities of the actual reality. ${ }^{77}$ In this sense, a critical theory of law and rights should understand the role of the struggle and the contradiction in all of their practices. Both negative and positive critiques are required, at least if we want something more than just a hypocritical discourse or a cynical but harmless practice.

75 Dworkin, supra note 3: 15.

76 Antonio Gramsci, Los obreros de la FIAT (Hombres de carne y hueso) in OdIO a LOS IndifeRENTES, 27-29 (Arial, 2011).

77 SANTOS, supra note 26: 15-17. 